\title{
Lifrarígræðslur á Íslandi: afturskyggn rannsókn á ábendingum og árangri
}

\author{
Lára Ósk Eggertsdóttir Claessen ${ }^{1}$ æknanemi, Einar Stefán Björnsson ${ }^{1,2}$ læknir, Óttar Már Bergmann² læknir, Sigurður Ólafsson² læknir
}

\section{ÁGRIP}

Inngangur: Lifrarígræðsla er mikilvægt meðferðarúrræði fyrir sjúklinga með lifrarbilun á lokastigi. Lifrarígræðslur eru ekki framkvæmdar hérlendis og sjúklingar pví sendir utan. Markmið pessarar rannsóknar var að kanna helstu ábendingar og árangur lifrarígræðslu hjá íslenskum sjúklingum. Efniviður og aðferðir: Rannsóknin var afturskyggn og náði til allra íslenskra sjúklinga sem höfðu gengist undir lifrarígræðslu frá fyrstu ígræðslu árið 1984 til loka 2012. Upplýsingum var safnað úr sjúkraskýrslum. Rannsóknartímabilinu var skipt í prjú undirtímabil til að meta breytingar á tíðni lifrarígræðsına og horfum.

Niðurstöður: Á rannsóknartímabilinu voru framkvæmdar 45 lifrarígræðslur, par af 5 endurígræðslur. Alls gengust 40 sjúklingar undir lifrarígræðslu, 16 karlar og 18 konur, meðalaldur 40 ár, og par af voru 6 börn, 2 stúlkur og 4 drengir á aldursbilinu 0,4-12 ára. Marktæk aukning var á fjölda ígræðsına á hverja milljón íbúa milli tímabila (2,40 1984-1996; 5,18
1997-2006 og 8,90 2007-2013; p<0,01). Helstu ábendingar fyrir ígræðslu voru skorpulifur með fylgikvillum hjá 26 sjúklingum (65\%), bráð lifrarbilun $6(15 \%)$, skorpulifur og lifrarfrumukrabbamein hjá premur (8\%), og önnur æxli en lifrarfrumukrabbamein hjá tveimur (5\%). Algengustu undirliggjandi sjúkdómar voru frumkomin gallskorpulifur (primary biliary cirrhosis) í 8 tilfellum (20\%), sjálfsofnæmislifrarbólga í fjórum (10\%), áfengistengd skorpulifur í premur $(7,5 \%)$ og frumkomin trefjunargallgangabólga (primary sclerosing cholangitis) í premur tilfellum (7,5\%). Meðalbiðtími var 5,9 mánuðir (miðgildi 3,2). Lifun var $84 \%$ eftir 1 ár og $63 \%$ eftir 5 ár og batnaði pegar leið á tímabilið.

Ályktanir: Lifrarígræðslum hefur fjölgað á undanförnum áratugum. Árangur peirra er góður og fer batnandi. Lifun sjúklinga er sambærileg við pað sem pekkist í löndum par sem lifrarígræðslur eru framkvæmdar.
${ }^{1}$ Læknadeild Háskóla Íslands, ${ }^{2}$ meltingarlækningaeiningu Landspítala. Sigurður Ólafsson sigurdol@landspitali.is

Greinin barst 3. júli 2015 sampykkt til birtingar 10. desember 2015

\section{Inngangur}

Lifrarígræðsla er mikilvægt meðferðarúrræði fyrir sjúklinga með lifrarbilun á lokastigi af völdum bráðra eða langvinnra lifrarsjúkdóma. Í fyrstu voru lifrarígræðslur aðeins framkvæmdar í tilraunaskyni en árið 1983 lýsti heilbrigðismálastofnun Bandaríkjanna pví yfir að lifrarígræðsla væri viðurkennd meðferð við lifrarsjúkdómum á lokastigi. Á Norðurlöndunum var farið að framkvæma lifrarígræðslur í byrjun 9. áratugarins og var fyrsta lifrarígræðslan framkvæmd í Helsinki 1984. ${ }^{1-4}$ Með tilkomu öflugra ónæmisbælandi lyfja og framfara í skurðlækningum hefur árangur af lifrarígræðslu og lifun farið mjög svo batnandi á undanförnum áratugum. Í Evrópu var 5 ára lifun eftir lifrarígræðslu 71\% á tímabilinu 1988-2013. ${ }^{5}$ Í Evrópu hafa yfir 100 púsund ígræðslur verið framkvæmdar frá upphafi ${ }^{6}$ og í Bandaríkjunum yfir 500 púsund ígræðslur á tímabilinu 1988-2013.?

Vísbendingar eru um verulega aukningu á nýgengi skorpulifrar hér á landi á undanförnum árum. ${ }^{8}$ Pví má búast við aukinni pörf fyrir lifrarígræðslu fyrir íslenska sjúklinga. Lifrarígræðslur hafa ekki verið gerðar hér á landi par sem fjöldinn er ekki nægilega mikill til að unnt sé að viðhalda pjálfun skurðlækna og annars fagfólks sem að aðgerðinni koma. Undirbúningur fyrir ígræðslu svo og eftirlit og meðferð sjúklinga eftir ígræðslu hefur hins vegar verið í höndum íslenskra lækna.

Mikilvægt er að fylgjast með árangri og fylgikvillum peirra sem gangast undir líffæraígræðslu. Að auki er mikilsvert að fylgjast með próun og tíðni pessara aðgerða svo hægt sé með nokkurri vissu að spá fyrir um pörfina fyrir petta meðferðarúrræði. Ekki hefur áður verið gerð rannsókn á lifrarígræðslu á Íslandi en markmið pessarar rannsóknar var að kanna ýmsa pætti sem snúa að lifrarígræðslu í íslenska sjúklinga, svo sem fjölda ígræðslna, ábendingar, biðtíma, lifun og ónæmisbælandi lyfjameðferð.

Fyrstu lifrarígræðslurnar í íslenska sjúklinga voru gerðar í Bretlandi en árin 1993-1996 voru pær gerðar á Sahlgrenska-sjúkrahúsinu í Gautaborg. Síðan var gerður samningur við Ríkisspítalann í Kaupmannahöfn og fyrsta lifrarígræðslan í íslenskan sjúkling par í borg var gerð árið 1999. Frá árinu 2009 hafa ígræðslurnar verið gerðar á Sahlgrenska-sjúkrahúsinu fyrir utan eina sem gerð var á Ríkisspítalanum í Osló. Lifrarígræðslur í börn hafa verið gerðar í Bandaríkjunum nema í eitt skipti par sem ígræðslan var gerð á Ríkisspítalanum í Osló.

\section{Efniviður og aðferðir}

Rannsóknin er lýsandi afturskyggn rannsókn sem náði til allra íslenskra sjúklinga sem gengust undir lifrarígræðslu til loka ársins 2012. Einn höfundanna (SÓ) fékk árið 1996 upplýsingar um sjúklinga sem fengið höfðu ígrædda lifur og hefur verið til nafnalisti síðan pó svo að skortur hafi verið á miðlægum gagnagrunni. Með pessum hætti tókst að hafa uppi á öllum íslenskum sjúklingum sem fóru í lifrarígræðslu fyrir lok ársins 2012 og mynduðu peir pýði rannsóknar- 


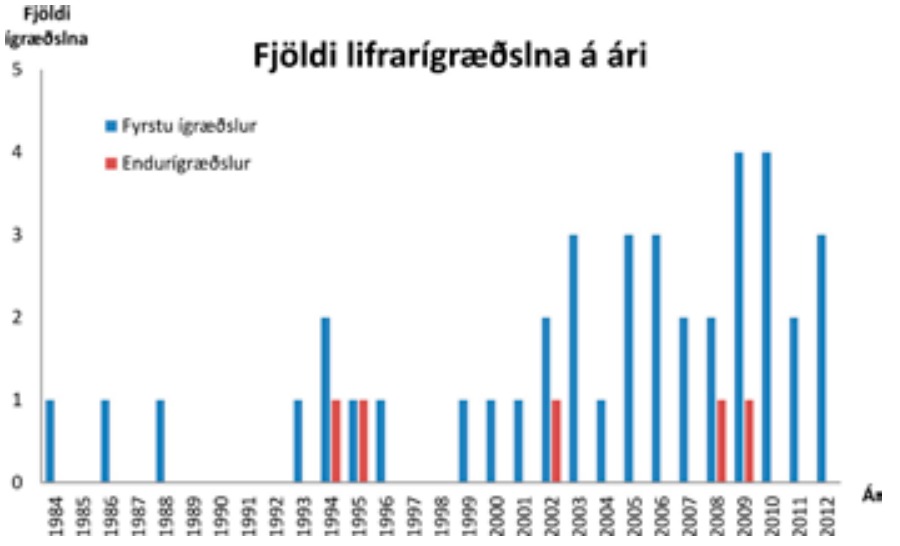

Mynd 1. Árlegur fjöldi fyrstu lifrarígræðslna og endurígræðsnla.

innar. Upplýsinga var aflað úr sjúkraskrám. Skráður var undirliggjandi lifrarsjúkdómur og ábending fyrir lifrarígræðslu. Pá var skráð ástand sjúklings við ígræðslu. Par sem gögn voru nægjanleg voru reiknuð MELD-stig (Model for End-Stage Liver Disease) (6-40 stig) sem eru notuð til að meta horfur sjúklinga og pörf fyrir lifrarígræðslu. Ef sjúklingur fær fleiri en 15 stig eru eins árs horfur að jafnaði betri með en án lifrarígræðslu. ${ }^{9,10}$ Einnig var skráð ChildPugh-flokkun á alvarleika lifrarsjúkdóms en sú flokkun var meira notuð áður en MELD-stigun varð ríkjandi. ${ }^{10}$ Biðtími eftir ígræðslu var jafnframt kannaður en hann er sá tími sem líður frá pví að einstaklingur er skráður á biðlista eftir lifur pangað til að lifrarígræðsla er framkvæmd. Biðtími vegna bráðrar lifrarbilunar er yfirleitt örfáir dagar og sá sjúklingahópur er almennt ekki talinn með pegar birtar eru tölur um biðtíma. Upplýsinga um biðtíma í Danmörku og Svípjóð var aflað og samanburður gerður. ${ }^{11,12}$ Pá var aflað upplýsinga um aðgerðina sjálfa og fylgikvilla hennar, ónæmisbælandi meðferð og langtímafylgikvilla líffæraígræðslu. Einnig var skráð lifun og hversu margir purftu endurígræðslu.

Rannsóknartímabilinu var skipt í prjú undirtímabil til samanburðar. Við skiptinguna var höfð til hliðsjónar skipting í norskri rannsókn sem gerð var á lifrarígræðslum par í landi. ${ }^{6}$ Einnig var reynt að hafa fjölda sjúklinga fyrir hvert tímabil pannig að unnt væri að gera tölfræðilega útreikninga.

Pær upplýsingar sem fengust við gagnasöfnun úr sjúkraskýrslum voru færðar inn í Microsoft Excel sem var notað við tölfræðiúrvinnslu gagnanna. Forritið R var notað við gerð KaplanMeier lifunargrafs og við útreikninga á marktækni á mun nýgengis á milli undirtímabila var notast við kí-kvaðratpróf. Pá var að auki leitað til starfandi tölfræðings við Háskóla Íslands eftir aðstoð við úrvinnslu. Tölfræðin í pessari rannsókn er að mestu lýsandi par sem markmiðið var að gera samantekt á ýmsum páttum tengdum
Tafla I. Fjöldi igræðsına á milljón íbúa eftir tímabilum.

\begin{tabular}{lcccc}
\hline Tímabil & $1984-1996$ & $1997-2006$ & $2007-2012$ & \\
\hline Fjöldi ígræðsIna & 8 & 15 & 17 & \\
\hline Ígræðslur á milljón íbúa & 2,4 & 5,2 & 8,9 & $\mathrm{p}<0,01$ \\
\hline
\end{tabular}

lifrarígræðslu. Mannfjöldatölur fyrir hvert ár rannsóknartímabilsins voru fengnar af vefsíðu Hagstofu Íslands. ${ }^{13}$

Öll tilskilin leyfi fyrir rannsókninni voru fengin hjá Vísindasiðanefnd (VSNb 2010100009/03.15), Persónuvernd (2010/887) og framkvæmdastjóra lækninga á Landspítala.

\section{Niðurstödur}

Rannsóknarpýdi

Alls fóru 40 sjúklingar í lifrarígræðslu frá árinu 1984, pegar fyrsta lifrarígræðslan á íslenskum sjúklingi var framkvæmd, til ársloka 2012. Af pessum 40 voru 6 börn $\leq 18$ ára (15\%), tvær stúlkur og fjórir drengir á aldursbilinu 0,4-12 ára, og 34 fullorðnir, 18 konur og 16 karlar. Í pýðinu voru 5 fullorðnir einstaklingar af erlendum uppruna.

Meðalaldur við ígræðslu fyrir pýðið í heild sinni var 40 ár og aldursbilið var 0,4-67 ár. Meðalaldur karla var 46 ár $(+/-14,5)$, kvenna 47 ár $(+/-12,5)$ og barna 4 ár $(+/-5,4)$.

\section{Fjöldi lifrarígræðslna}

Alls voru framkvæmdar 45 lifrarígræðslur á 40 sjúklingum, 40 voru fyrstu lifrarígræðslur og 5 endurígræðslur (11\%). Ígræðslum fjölgaði pegar leið á rannsóknartímabilið (mynd 1). Við samanburð milli priggja tímabila kemur fram að árin 1984-1996 voru aðeins 8 ígræðslur gerðar, en árin 2007-2012 voru lifrarígræðslur alls 17 (tafla I).

Meðalfjöldi lifrarígræðslna á milljón íbúa fyrir allt rannsóknartímabilið var 4,7. Marktæk aukning var á fjölda lifrarígræðslna á milljón íbúa á tímabilinu (tafla I). Á árunum 2007-2012 voru 8,9 lifrarígræðslur í íslenska sjúklinga á hverja milljón íbúa á ári.

Flestar ígræðslur voru framkvæmdar í Svípjóð, 16 talsins, í Danmörku 15, Bandaríkjunum 5, Noregi tvær og í Bretlandi tvær.

Í flestum tilvikum var notuð lifur úr látnum gjafa. Í 34 tilvikum var notuð heil lifur úr látnum gjafa en prír sjúklingar fengu lifrarhluta, par af tvö börn (split liver transplant). Prír sjúklingar, allt börn, fengu lifrarhluta úr lifandi gjafa.

Tafla II. Ábendingar fyrir lifrarígræðslu.

\begin{tabular}{|c|c|c|c|c|c|}
\hline Ábendingar fyrir lifrarígræðslu & Allir $n=40$ & $\%$ af heild & Karlar $n=16(\%)$ & Konur $\mathrm{n}=18(\%)$ & Börn $n=6(\%)$ \\
\hline Skorpulifur & 26 & 65 & $10(63)$ & $12(67)$ & $4(67)$ \\
\hline Skorpulifur og lifrarfrumukrabbamein & 3 & 8 & $3(19)$ & 0 & 0 \\
\hline Æxli önnur en lifrarfrumukrabbamein & 2 & 5 & 0 & $2(11)$ & 0 \\
\hline Bráđ lifrarbilun & 6 & 15 & $2(13)$ & $4(22)$ & 0 \\
\hline Aðrar ábendingar & 3 & 8 & $1(6)$ & 0 & $2(33)$ \\
\hline
\end{tabular}




\section{Ábendingar fyrir lifrarígræðslu}

Algengasta ábending fyrir lifrarígræðslu var skorpulifur, 26 sjúklingar af 40 (65\%). Hjá premur af pessum 26 fannst lifrarfrumukrabbamein í undirbúningsferli fyrir lifrarígræðslu og telst skorpulifur en ekki æxlið ábendingin fyrir ígræðslu í peim tilvikum (tafla II). Hjá 6 sjúklingum (15\%) var bráð lifrarbilun ástæða lifrarígræðslu. Par af voru prjú tilfelli vegna lifrarskaða af völdum lyfja, tvö vegna parasetamól-eitrunar og eitt vegna berklalyfsins ísóníazíð. Eitt tilfelli var Wilson-sjúkdómur, eitt bráð lifrarbólga B og í einu tilviki var orsök lifrarbilunar ópekkt. Æxli í lifur var ábending fyrir lifrarígræðslu hjá alls 5 sjúklingum (13\%). Í premur tilvikum (8\%) var ábendingin lifrarfrumukrabbamein og í tveimur tilvikum (5\%) var um hemangioendothelioma að ræða. Einn sjúklingur sem hafði lifrarfrumukrabbamein var við listun með tvö æxli af stærðinni 2,5 x 1,1 cm og 1,5 x 1,17 cm. Annar sjúklingur var með tvö æxli af stærðinni 2,7 cm í pvermál og 2,7 x 1,7 cm sem voru staðsett í lifrarhluta V og VIII. Heildarpvermál var pví $6,6 \mathrm{~cm}$. Priðji sjúklingurinn hafði eitt $2 \mathrm{~cm}$ æxli í lifrarhluta VIII. Allir uppfylltu pví svokölluð Milan-skilmerki fyrir lifrarígræðslu vegna lifrarfrumukrabbameins. ${ }^{14}$

Pannig voru alls 6 sjúklingar sem gengust undir lifrarígræðslu með lifrarfrumukrabbamein. Allir voru með undirliggjandi skorpulifur pannig að í heild var skorpulifur til staðar hjá 29 lifrarpegum (73\%).

Ábendingar lifrarígræðslna fyrir hvert undirtímabil voru bornar saman. Ef tekin eru með prjú tilfelli par sem lifrarfrumukrabbamein var ábending lifrarígræðslu en skorpulifur jafnframt til staðar, sést sterk vísbending um aukningu á lifrarpegum með skorpulifur á milli tímabila. Á fyrsta undirtímabilinu, frá 1984 til 1996, var skorpulifur ábending fyrir ígræðslu hjá 7 einstaklingum. Á árunum 1997-2006 var skorpulifur ábending fyrir 10 lifrarígræðslum og 2007-2012 var pað ábending fyrir 12 ígræðslum. Pessi aukning var á mörkum pess að vera marktæk $(\mathrm{p}=0,056)$.

Tafla III. Ábendingar fyrir lifrarígræðslu.

\begin{tabular}{lcc}
\hline Ábendingar lifrarígræðslu & Fjöldi $n=40$ & $\%$ af heild \\
\hline Frumkomin gallskorpulifur & 8 & 20 \\
\hline Bráð lifrarbilun & 6 & 15 \\
\hline Sjálfsofnæmislifrarbólga & 4 & 10 \\
\hline Áfengistengd skorpulifur & 3 & 7,5 \\
\hline Frumkomin trefjunargallgangabólga & 3 & 7,5 \\
\hline Skorpulifur og lifrarfrumukrabbamein & 3 & 7,5 \\
\hline Gallgangalokun & 2 & 5 \\
\hline FExli önnur en lifrarfrumukrabbamein & 2 & 5 \\
\hline Afleidd trefjunargallgangabólga & 1 & 2,5 \\
\hline Blöðrunýrnasjúkdómur & 1 & 2,5 \\
\hline Ópekkt orsök & 1 & 2,5 \\
\hline Gallgangafæð af ópekktri orsök hjá fullorðnum & 1 & 2,5 \\
\hline Járnhleðslukvilli & 1 & 2,5 \\
\hline Lifrarbólga C og áfengi & 1 & 2,5 \\
\hline Fitulifrarkvilli* & 1 & 2,5 \\
\hline Nýburalifrarbólga & 1 & 2,5 \\
\hline Ágeng ættgeng innanlifrargallstífla & 1 & 2,5 \\
\hline *Fitulifrarkvilli sem okki tengist áfengisneyslu & &
\end{tabular}

${ }^{*}$ Fitulifrarkvilli sem ekki tengist áfengisneyslu.
Frumkomin gallskorpulifur var ábending fyrir ígræðslu hjá 8 einstaklingum og bráð lifrarbilun hjá 6 og pví voru petta algengustu ábendingar fyrir lifrarígræðslu (tafla III). Sjálfsofnæmislifrarbólga, áfengistengd skorpulifur og frumkomin trefjunargallgangabólga komu á eftir. Aðeins einn sjúklingur var með lifrarbólgu $C$ en misnotkun áfengis var jafnframt meðvirkandi páttur í pví tilfelli. Einungis einn einstaklingur hafði fitulifrarkvilla sem ekki tengdist áfengismisnotkun. Ábendingar fyrir lifrarígræðslu barna voru sjálfsofnæmislifrarbólga, ágeng ættgeng innanlifrargallstífla, arfgengur blöðrunýrnasjúkdómur, nýburalifrarbólga og gallgangalokun (biliary atresia) í tveimur tilvikum.

Meðal sjaldgæfari sjúkdóma voru afleidd trefjunargallgangabólga (secondary sclerosing cholangitis), lifrarsjúkdómur tengdur arfgengum blöðrunýrnasjúkdómi með víkjandi erfðamáta (autosomal recessive polycystic kidney disease) og ágeng ættgeng innanlifrargallstífla (progressive familial intrahepatic cholestasis). Sjúklingur með arfgengan blöðrunýrnasjúkdóm fór bæði í lifrar- og nýrnaígræðslu og var nýrnaígræðslan gerð mánuði áður en lifrarígræðslan var gerð.

\section{Endurígræðslur}

Endurígræðslur voru 5 af 45 (11\%). Ástæður endurígræðslu voru blæðingar og sýkingar í kjölfar aðgerðar $(n=1) 11$ mánuðum eftir fyrri ígræðslu, blóðsegi í lifrarslagæð (n=1) rúmum mánuði eftir fyrri ígræðslu, ígerð í lifur tveimur mánuðum eftir fyrri ígræðslu $(\mathrm{n}=1)$, afleidd trefjunargallgangabólga rúmum premur árum eftir frumígræðslu (n=1) og gallleki og sýkingar í gallvegum (n=1) premur mánuðum eftir frumígræðslu. Enginn fór oftar en einu sinni í endurígræðslu.

\section{MELD, Child-Pugh-flokkun og fylgikvillar skorpulifrar}

Unnt var að reikna MELD-stig fyrir 19 sjúklinga við listun og 14 sjúklinga við ígræðslu. Child-Pugh-flokkun var hægt að reikna fyrir 26 sjúklinga við listun og 25 við ígræðslu. Meðaltal MELDstiga við ígræðslu var 22 með miðgildi 17. Frá árinu 2009 pegar lifrarígræðslur fluttust til Gautaborgar var MELD-skor við ígræðslu að meðaltali 17,6 og miðgildi 13. Við ígræðslu var einn í ChildPugh-flokki A, 8 í flokki B og 16 í flokki C.

Vökvasöfnun í kvið (ascites) var algengasti fylgikvilli skorpulifrar og var til staðar hjá 17 af 29 (59\%) sem höfðu skorpulifur. Sjálfsprottin sýking í kviðarholsvökva (spontaneous bacterial peritonitis) greindist hjá 5 af peim sem fengu vökvasöfnun í kvið (17\%). Lifrarheilakvilli og blæðing frá æðagúlum voru einnig áberandi fylgikvillar.

\section{Biðtími eftir lifrarígræðslu}

Meðalbiðtími fyrir allt rannsóknartímabilið var 5,9 mánuðir með miðgildi 3,2 mánuðir. Ekki reyndist marktæk lenging á biðtíma milli tímabila. Meðalbiðtími peirra 10 íslensku sjúklinga sem fóru í lifrarígræðslu í Gautaborg á tímabilinu 2009-2012 var 4,4 mánuðir með miðgildi 3,65. Síðustu 5 ár rannsóknartímabilsins létust tveir sjúklingar á biðlista eftir lifrarígræðslu. Annar varð óskurðtækur 


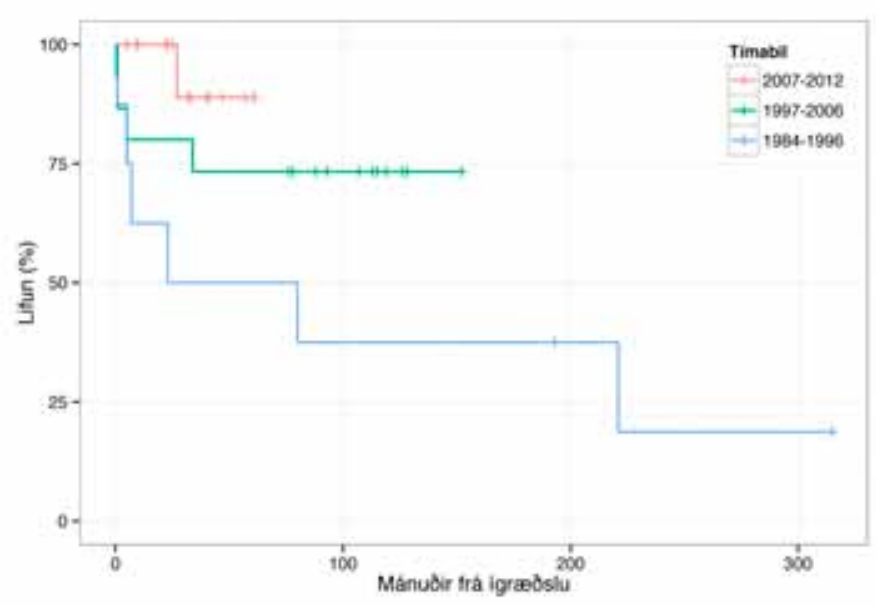

Mynd 2. Kaplan-Meier lifunargraf sem sýnir lifun eftir tímabilum.

á biðlista vegna stækkandi lifrarfrumukrabbameins og hinn lést vegna blæðingar í heila.

\section{Lifun og fylgikvillar}

Af 40 sjúklingum sem gengust undir lifrarígræðslu á rannsóknartímabilinu höfðu 11 látist við lok árs 2012 (28\%). Í sumum tilfellum voru dánarorsakir líklega fleiri en ein. Fjórir sjúklingar dóu úr illkynja sjúkdómum: flögubekjukrabbameini í vélinda, smáfrumukrabbameini í lunga, ígræðslutengdu eitilfrumukrabbameini (post transplant lymphoproliferative disorder) og lifrarfrumukrabbameini. prír höfðu lungnabólgu og 5 höfðu aðrar sýkingar. Lifrarbilun var dánarorsök hjá premur sjúklingum. Einn sjúklingur dó í ígræðsluaðgerðinni, hugsanlega vegna blóðsega í lungum.

Lifun eftir lifrarígræðslu var 84\% eftir eitt ár og 63\% eftir 5 ár (tafla IV). Lifun jókst eftir pví sem leið á tímabilið (tafla IV, mynd 2). Lifun var slök í upphafi par sem 5 einstaklingar af 8 sem fóru í ígræðslu á tímabilinu 1984-1996 dóu fyrir árið 1996.

Af peim premur börnum sem fengu lifrarhluta frá lifandi gjafa voru tvö enn á lífi við lok rannsóknartímabilsins. Eitt barnið lést úr lungnabólgu rúmum tveimur og hálfu ári eftir ígræðslu.

Af peim premur einstaklingum sem fóru í lifrarígræðslu vegna lifrarfrumukrabbameins lést einn á rannsóknartímabilinu en hann lifði í tvö ár og prjá mánuði eftir lifrarígræðslu.

Fylgikvillar á aðgerðartímabili (perioperative period) komu upp hjá alls 21 sjúklingi (53\%). Algengustu fylgikvillar aðgerðar tengdust gallvegum en alls fengu 6 sjúklingar gallvegatengd vandamál svo sem gallleka (fjórir sjúklingar) og gallstíflu (tveir sjúklingar).

Höfnun á lifrargræðlingi kom fram 15 sinnum hjá 13 sjúklingum (33\%). Í öllum tilvikum var góð svörun við háskammta sykursterameðferð fyrir utan eitt tilvik par sem beita purfti meðferð með mótefnum gegn T-frumum (anti thymocyte globulin) auk háskammta sykursterameðferðar í æð. Tími frá lifrarígræðslu að höfnun var að meðaltali 6,9 mánuðir, miðgildi 2,9 mánuðir.

Fjórir sjúklingar fengu aftur frumsjúkdóminn í hina ígræddu lifur. Peir sjúkdómar sem um var að ræða voru sjálfsofnæmislifrarbólga (tvö tilfelli), frumkomin gallskorpulifur og frumkomin trefjunargallgangabólga. Meðaltími frá lifrarígræðslu að endur-
Tafla IV. Eins árs og 5 ára lifun lifrarpega. Ekki var reiknuð 5 ára lifun fyrir 20072012 par sem stuttur tími var frá aðgerð.

\begin{tabular}{lcccc}
\hline Tímabil & $1984-2012$ & $1984-1996$ & $1997-2006$ & $2007-2012$ \\
\hline 1 árs lifun & $84 \%$ & $63 \%$ & $80 \%$ & $100 \%$ \\
\hline 5 ára lifun & $63 \%$ & $50 \%$ & $73 \%$ & -- \\
\hline
\end{tabular}

Tafla V. Helstu ónæmisbælandi lyf íslenskra lifrarpega.

\begin{tabular}{lccc}
\hline Lyf & Eftir ígræðslu $n=32(\%)$ & Eftir ár $n=21(\%)$ & Eftir 5 ár (\%) \\
\hline Ciklósporín & $7(22)$ & $3(14)$ & $3(21)$ \\
\hline Azatíóprín & $6(19)$ & $5(24)$ & $6(43)$ \\
\hline Prednisólón & $24(75)$ & $7(33)$ & $4(29)$ \\
\hline Takrólímus & $25(78)$ & $18(86)$ & $11(79)$ \\
\hline Mýcófenólsýra & $22(69)$ & $8(38)$ & $3(21)$ \\
\hline Sirólímus & $0(0)$ & $1(5)$ & $0(0)$
\end{tabular}

komu sjúkdóms var 9,3 ár, miðgildi 10,1 ár. Endurkoma frumsjúkdóms leiddi pó ekki til endurígræðslu hjá neinum.

\section{Ónæmisbælandi lyfjameðferð}

Upplýsingar fengust um lyf 32 einstaklinga strax eftir ígræðslu, 21 einstaklings premur árum eftir ígræðslu og 14 einstaklinga 5 árum eftir ígræðslu. Algengt var að sjúklingar væru á priggja lyfja meðferð með takrólímus, mýcófenólsýru og prednisólón strax í kjölfar ígræðslu. Takrólímus var algengasta ónæmisbælandi lyfið en 25 einstaklingar voru á pví strax eftir ígræðslu, 18 eftir prjú ár og 11 eftir 5 ár (tafla V).

Illkynja sjúkdómar greindust hjá 8 sjúklingum: Eitilfrumumein í kjölfar ígræðslu (post transplant lymphoproliferative disorder, PTLD) greindist hjá premur sjúklingum, flögupekjukrabbamein í hálsi (einn sjúklingur) og í andliti (einn sjúklingur), smáfrumukrabbamein í lungum (einn sjúklingur), innanpekjuæxlismyndun í leghálsi af stigi II (cervical intraepithelial neoplasia II, einn sjúklingur) og eitilfrumukrabbamein (einn sjúklingur).

\section{Umræður}

Meginniðurstöður rannsóknarinnar voru að lifrarígræðslum hefur farið fjölgandi á rannsóknartímabilinu og lifun hefur batnað og er sambærileg við pað sem pekkist í löndum par sem lifrarígræðslur eru framkvæmdar. ${ }^{3-5,11,12,15}$ Frumkomin gallskorpulifur var algengasta ábendingin fyrir ígræðslu.

Mjög fáir sjúklingar fóru í ígræðslu í kjölfar fyrstu ígræðslunnar árið 1984 en ígræðslum hefur fjölgað undanfarin ár og eru skýringar vafalítið nokkrar. Gera má ráð fyrir að pekking á lifrarígræðslu sem meðferðarúrræði og reynsla af mati og undirbúningi sjúklinga hafi verið minni meðal íslenskra lækna í upphafi tímabilsins og færri sjúklingar sendir utan af peim ástæðum.

Fjölgun sjúklinga með lifrarsjúkdóm á lokastigi er pó líklega meginskýringin á fjölgun lifrarígræðslna á tímabilinu. Flestir lifrarpegar hafa sögu um skorpulifur en nýgengi og dánartíðni skorpulifrar hér á landi hefur lengst af verið með pví lægsta sem pekkist. ${ }^{16}$ Hins vegar benda fyrstu niðurstöður framskyggnrar 
rannsóknar til verulegrar aukningar á nýjum tilfellum skorpulifrar. $^{8}$

Pó sjúklingum með ígrædda lifur fari fjölgandi hafa tiltölulega færri íslenskir sjúklingar farið í lifrarígræðslu en pekkist í mörgum öðrum vestrænum löndum. Nærtækastur er samanburður við Norðurlöndin. Á tímabilinu 2007-2012 voru 8,9 lifrarígræðslur í íslenska sjúklinga á hverja milljón íbúa á ári. Á sama tímabili voru framkvæmdar 17,5 ígræðslur á hverja milljón íbúa í Noregi, 15,4 í Svípjóð, 9,5 í Finnlandi og 8,2 í Danmörku. ${ }^{11}$

Margir aðrir pættir hafa áhrif á fjölda lifrarígræðslna, svo sem algengi lifrarsjúkdóma, framboð gjafalíffæra og fleira. Pótt nýgengi skorpulifrar á Íslandi hafi aukist, hefur pað lengst af verið mun lægra en í samanburðarlöndunum. Rannsókn sem kannaði nýgengi skorpulifrar á Íslandi og Svípjóð leiddi í ljós að nýgengi skorpulifrar á Íslandi var aðeins 3,3 á 100.000 íbúa en 15,3 á 100.000 íbúa í Gautaborg í Svípjóð. ${ }^{17}$ Norsk rannsókn sýndi fram á að nýgengi skorpulifrar par í landi var 13,4 á 100.000 íbúa sem einnig er töluvert hærra en á Íslandi. ${ }^{18}$ Mun á nýgengi á Íslandi annars vegar og í Svípjóð og Noregi hins vegar má líklega skýra með pví að ýmsar undirliggjandi orsakir skorpulifrar eru misalgengar á milli landanna. Áfengistengd skorpulifur var mun algengari í Svípjóð (50\%) en á Íslandi (29\%) auk pess sem skorpulifur vegna lifrarbólgu C var algengari í Svípjóð (21\%) en á Íslandi (8\%). Helstu undirliggjandi orsakir skorpulifrar í Noregi voru svipaðar peim sem sáust í Svípjóð en áfengistengd skorpulifur var til staðar hjá $53 \%$ norskra skorpulifrarsjúklinga og lifrarbólga C hjá $10 \%{ }^{18}$

Í Noregi er fjöldi líffæragjafa mestur á Norðurlöndunum og biðtími eftir lifur mjög stuttur í alpjóðlegum samanburði, en meðalbiðtími fyrir tímabilið 2007-2012 var rúmlega mánuður. ${ }^{11}$ Athyglisvert er að prátt fyrir að nýgengi skorpulifrar í Danmörku sé 33 á 100.000 íbúa, sem er pað hæsta sem pekkist á Norðurlöndum, er fjöldi lifrarígræðslna á milljón íbúa svipaður og hér á landi. ${ }^{18-20}$ Möguleg skýring á pessu gæti verið að Danir beiti ekki lifrarígræðslu í sama mæli og hin Norðurlöndin sem meðferðarúrræði gegn skorpulifur. Einnig gæti sú staðreynd að hátt hlutfall skorpulifrar í Danmörku er áfengistengd (79\%) valdið pví að fjöldi lifrarígræðslna er minni en búast mætti við par sem lifrarígræðsla vegna áfengistengdrar skorpulifrar er háð ströngum skilyrðum. ${ }^{18-20}$ Pá gæti minna framboð gjafalifra í Danmörku miðað við hin Norðurlöndin haft áhrif, en biðtími eftir lifur er lengri í Danmörku en á hinum Norðurlöndunum. ${ }^{12}$

Ein möguleg skýring á tiltölulega fáum lifrarígræðslum í íslenska sjúklinga gæti verið að peir séu ekki sendir í ígræðslu í sama mæli og annars staðar pó ábending sé fyrir hendi vegna ólíkrar nálgunar við meðferð lifrarsjúklinga og vegna pess að lifrarígræðslur eru ekki framkvæmdar hér á landi. •að verður að teljast ólíklegt par sem sérfræðingar í meltingarlækningum hafa séð um pessa sjúklinga frá upphafi og undanfarin ár hafa starfað hér læknar með sérpekkingu í lifrarlækningum. Pá hafa sömu viðmið verið notuð hér á landi við mat og undirbúning fyrir lifrarígræðslu og pekkist við ígræðslusjúkrahús bæði í Evrópu og í Bandaríkjunum. Samningar sem gerðir hafa verið við ígræðslusjúkrahús á Norðurlöndum um líffæraígræðslur fyrir íslenska sjúklinga veita peim einnig sama rétt og íbúum viðkomandi landa.

Frumkomin gallskorpulifur var algengasta ábending fyrir lifrarígræðslu hér á landi en einnig voru bráð lifrarbilun, sjálfsof- næmislifrarbólga og frumkomin trefjunargallgangabólga ofarlega á lista. Hlutfall pessara sjúkdóma hefur pó minnkað, sérstaklega á síðasta tímabili rannsóknarinnar.

Nýleg rannsókn sýnir að algengi frumkominnar gallskorpulifrar á Íslandi var 38,3 tilfelli á 100.000 íbúa, sem er með pví hæsta sem pekkist. ${ }^{21}$ Algengasti undirliggjandi sjúkdómur skorpulifrar hjá lifrarpegum á Norðurlöndum undanfarin ár hefur hins vegar verið frumkomin trefjunargallgangabólga ${ }^{11,12}$ en athyglisvert er að í pessari rannsókn var frumkomin trefjunargallgangabólga undirliggjandi orsök skorpulifrar hjá einungis premur sjúklingum (8\%). Ekki hafa verið birtar niðurstöður rannsókna á algengi frumkominnar trefjunargallgangabólgu hér á landi.

Pótt frumkomin gallskorpulifur sé algengasta ábendingin fyrir lifrarígræðslu greinast mun fleiri sjúklingar hér á landi með skorpulifur af völdum áfengis. ${ }^{8,21}$ Ástæða pess að fáir sjúklingar með skorpulifur af völdum áfengis fara í lifrarígræðslu er meðal annars sú að slíkir sjúklingar hafa yfirleitt purft að uppfylla skilyrði, svo sem að hafa ekki neytt áfengis í að minnsta kosti hálft ár auk pess sem oftast er gerð krafa um að sjúklingur hafi gengist undir áfengismeðferð.

Víða í Evrópu og í Bandaríkjunum er lifrarsjúkdómur af völdum lifrarbólgu $C$ algengasta ábendingin fyrir lifrarígræðslu ${ }^{2,11,22}$ en aðeins einn íslenskur sjúklingur sem gekkst undir lifrarígræðslu var smitaður af lifrarbólgu C. Petta gæti skýrst af pví að lifrarbólga $\mathrm{C}$ fór ekki að breiðast út á meðal sprautufíkla hérlendis fyrr en tiltölulega seint og próun skorpulifrar tekur langan tíma. ${ }^{23}$ Sífellt fleiri lifrarpegar á Norðurlöndum eru með lifrarbólgu C, eða 14\% á árinu $2011 .^{11}$

Lifrarfrumukrabbamein greindist hjá 6 sjúklingum í pessari rannsókn og höfðu peir allir undirliggjandi skorpulifur. Lifrarígræðsla er að jafnaði ekki gerð hjá sjúklingum með lifrarfrumukrabbamein nema ákveðin skilmerki sem snúa að stærð og útbreiðslu æxlis séu uppfyllt. Sé slíkum viðmiðum framfylgt er árangur mjög góður. Lifrarfrumukrabbamein hefur á síðustu árum verið ein algengasta ábending fyrir lifrarígræðslu á Norðurlöndunum. ${ }^{11}$

Í norskri rannsókn var lifun 90\% eftir eitt ár og 83\% eftir 5 ár fyrir tímabilið 1984-2008 og er pað svipað og á Norðurlöndum í heild sinni. ${ }^{11}$ Hér á landi var lifun fyrir allt rannsóknartímabilið $84 \%$ eftir eitt ár og $63 \%$ eftir 5 ár sem telst frekar gott. Í upphafi var lifun slök og 5 einstaklingar af peim 8 sem fóru í ígræðslu á tímabilinu 1984-1996 létust fyrir árið 1996. Lifun fór pó batnandi eftir pví sem leið á rannsóknartímabilið og er nú sambærileg við pað sem pekkist á ígræðslusjúkrahúsum í vestrænum löndum. Pessi árangur verður að teljast athyglisverður par sem ekki eru framkvæmdar lifrarígræðslur hér á landi.

Niðurstöður rannsóknarinnar verður að skoða í ljósi peirra sérstöku aðstæðna að ígræðsluaðgerðin fer fram erlendis en undirbúningur og eftirmeðferð hér á landi. Slíkar kringumstæður gætu leitt til lakara aðgengis að gjafalifrum og verri árangurs. Meðalbiðtími peirra 10 íslensku sjúklinga sem fóru í lifrarígræðslu í Gautaborg á tímabilinu 2009-2012 var 4,4 mánuðir með miðgildi 3,65. Til samanburðar var meðalbiðtími eftir lifrarígræðslu í Gautaborg fyrir sama tímabil 3,4 mánuðir, miðgildi 1,54 mánuðir.11,12 Lifun eftir ígræðslu er pó sambærileg við pað sem pekkist annars staðar á Norðurlöndum. ${ }^{24}$ 
Helstu veikleikar pessarar rannsóknar eru meðal annars að hún er afturskyggn og pýði rannsóknarinnar smátt, sem gerði tölfræðilega útreikinga og samanburð við önnur lönd erfiðari. Rannsóknartímabilið er að auki nokkuð langt og ýmsar framfarir á sviði lifrarígræðslna hafa orðið á tímabilinu og stuðlað að bættum árangri og lifun. Pá má einnig nefna að skráningu upplýsinga um lifrarpega var nokkuð ábótavant, pá aðallega á fyrri hluta rannsóknartímabils. Par að auki var í vissum tilvikum skortur á upplýsingum frá ígræðslusjúkrahúsum erlendis varðandi aðgerðirnar og sjúkdómsgang í legu.

Athugun okkar sýnir að lifrarígræðslu er í vaxandi mæli beitt hér á landi við meðferð lifrarsjúkdóma á lokastigi. Aukninguna má líklega rekja til vaxandi nýgengis skorpulifrar en aðrir pættir kunna einnig að hafa áhrif. Árangur lifrarígræðslu hjá íslenskum sjúklingum er góður. Líklegt er að vegna vaxandi nýgengi lifrarsjúkdóma muni pörfin fyrir lifrarígræðslu halda áfram að aukast hér á landi.

\section{Pakkir}

Höfundar pakka Sigrúnu Helgu Lund fyrir veitta aðstoð við tölfræðilega úrvinnslu.

\section{Heimildir}

1. Starzl TE. The long reach of liver transplantation. Experimental and clinical transplantation : official journal of the Middle East Society for Organ Transplantation. 2013;11(3):87-92.

2. Adam R, Karam V, Delvart V, O'Grady J, Mirza D, Klempnauer J, et al. Evolution of indications and results of liver transplantation in Europe. A report from the European Liver Transplant Registry (ELTR). J Hepatol 2012; 57: 675-88

3. Björo K, Friman S, Höckerstedt K, Kirkegaard P, Keiding $\mathrm{S}$, Schrumpf E, et al. Liver transplantation in the Nordic countries, 1982-1998: changes of indications and improving results. Scand J Gastroenterol 1999: 34: 714-22.

4. Scholz T, Karlsen TH, Sanengen T, Schrumpf E, Line PD, Boberg KM, et al. Levertransplantasjon i Norge gjennom 25 ar. Tidssk Nor Laegeforen 2009; 129: 2587-92.

5. The European Liver Transplant Registry. Results: Patient and graft survival following liver transplantation $05 / 1968$ - 12/2013. eltr.org - nóvember 2015.

6. $\mathrm{R}$ The European Liver Transplant Registry. Results: Evolution of 118,364 liver transplantations in Europe. eltr. org - nóvember 2015

7. Organ Procurement and Transplantation Network. National data by state 1988-2014. optn.transplant.hrsa. gov/. - nóvember 2015.

8. Ólafsson S, Bergmann Ó, Jónasson JG, Björnsson E. Major increase in the incidence of cirrhosis in Iceland - results of a nationwide populationbased study. Hepatology 2011; 54: Suppl 4: A460.
9. Florman S, Miller CM. Live donor liver transplantation. Liver Transpl 2006; 12: 499-510.

10. Kamath PS, Kim WR. The model for end-stage liver disease (MELD). Hepatology 2007; 45: 797-805.

11. Karlsen TH. The Nordic Liver Transplant Registry (NLTR), annual report 2011. 2012

12. Scandiatransplant. Committees: Nordic Liver Transplantation Group, Annual reports 2000-2012. scandiatransplant.org/ - nóvember 2015.

13. Vefsíða Hagstofu Íslands, hagstofa.is/

14. Guerrini GP, Pinelli D, Di Benedetto F, Marini E, Corno $\mathrm{V}$, Guizzetti M, et al. Predictive value of nodule size and differentiation in HCC recurrence after liver transplantation. Surg Oncol 2015; S0960-7404 (15) 30025-6.

15. Watt KD, Pedersen RA, Kremers WK, Heimbach JK, Charlton MR. Evolution of causes and risk factors for mortality post-liver transplant: results of the NIDDK longterm follow-up study. Am J Transplant 2010; 10: 1420-7.

16. Lúðvíksdóttir D, Skúlason $H$, Jakobsson $F$, Pórisdóttir A, Cariglia N, Magnússon B, et al. Epidemiology of liver cirrhosis morbidity and mortality in Iceland. Eur J Gastroenterol Hepatol 1997; 9: 61-6.

17. Gunnarsdottir SA, Olsson R, Olafsson S, Cariglia N, Westin J, Thjodleifsson B, et al. Liver cirrhosis in Iceland and Sweden: incidence, aetiology and outcomes. Scand J Gastroenterol 2009; 44: 984-93.

18. Haukeland JW, Lorgen I, Schreiner LT, Frigstad SO, Brandsaeter $\mathrm{B}, \mathrm{Björo} \mathrm{K}$, et al. Incidence rates and causes of cirrhosis in a Norwegian population. Scand J Gastroenterol 2007; 42: 1501-8.
19. Olafsson S, Bjornsson ES. Differences and similarities in the etiology and the incidence of cirrhosis in the Nordic countries. Scand J Gastroenterol 2013; 48: 509-10.

20. Dam Fialla A, Schaffalitzky de Muckadell OB, Touborg Lassen A. Incidence, etiology and mortality of cirrhosis: a population-based cohort study. Scand J Gastroenterol 2012; 47: 702-9.

21. Baldursdottir TR, Bergmann OM, Jonasson JG, Ludviksson BR, Axelsson TA, Bjornsson ES. The epidemiology and natural history of primary biliary cirrhosis: a nationwide population-based study. Eur J Gastroenterol Hepatol 2012; 24: 824-30.

22. Wong RJ, Aguilar M, Cheung R, Perumpail RB, Harrison SA, Younossi ZM, et al, Nonalcoholic steatohepatitis is the second leading etiology of liver disease among adults awaiting liver transplantation in the United States. Gastroenterology 2015; 148: 547-55.

23. Ársrit SÁÁ. 2007-2010. Reykjavík 2012.

24. Fosby B, Melum E, Bjøro K, Bennet W, Rasmussen A, Andersen IM, et al. Liver Transplantation in the Nordic Countries - An Intention to Treat and Post-Transplant Analysis from The Nordic Liver Transplant Registry 1982-2013. Scand J Gastroenterol 2015; 50: 797-808.

\section{Liver transplantation in Iceland: a retrospective study of indications and results}

\section{Eggertsdóttir Claessen LO'1, Björnsson $\mathrm{ES}^{1,2}$, Bergmann $\mathrm{OM}^{2}$, Olafsson $\mathrm{S}^{2}$}

Background/Aims: Liver transplantation is an important treatment option for end-stage liver disease. Since liver transplantation is not performed in Iceland, patients are sent abroad for this procedure. The aim of this study was to investigate indications and results of liver transplantations for Icelandic patients.

Materials and methods: The study was retrospective and included all patients in Iceland who had undergone liver transplantation from the first transplantation in 1984 to the end of 2012. Information was gathered from medical records. The study period was divided into three subperiods in order to evaluate changes in frequency of transplantation and survival.

Results: During the period, 45 liver transplantations, thereof five retransplantations, were performed. Of 40 patients 16 were males, 18 females, mean age 40 years. There were six children, 2 girls and 4 boys with an age range of $0.4-12$ years. Number of transplantation per million inhabitants increased significantly ( 2.40 during 1984-1996; 5.18 during $1997-2006$ and 8.90 during $2007-2013 ; p<0.01)$. The main indication for transplantation was cirrhosis with complications in 26 patients $(65 \%)$, acute liver failure in $6(15 \%)$, cirrhosis and hepatocellular carcinoma in three (8\%), and hemangioendothelioma in two (5\%). The most common underlying liver diseases were primary biliary cirrhosis in $8(20 \%)$, autoimmune hepatitis in four (10\%), alcoholic cirrhosis in three $(7.5 \%)$ and primary sclerosing cholangitis in three (7.5\%). The mean waiting time for transplantation was 5.9 months (median 3.2). Survial was $84 \%$ in one year and $63 \%$ in 5 years. Survival increased during the study period. Conclusions: The number of liver transplantations has increased significantly in recent years. Survival has improved and is comparable to survival in countries where liver transplantations are performed. 